ISSN III9-7455

\title{
Research Note \\ EFFECT OF GROWTH ENHANCEMENT AGRO-INPUT SUPPORT ON RICE OUTPUT: EMERGING ISSUES FOR THE GREEN ECONOMY IN NIGERIA
}

\author{
Coker, A. A. \\ ${ }^{1}$ Department of Agricultural Economics and Extension Technology, School of Agriculture and \\ Agricultural Technology, Federal University of \\ Technology, Minna, P.M.B. 65, Minna, Nigeria. \\ E-mail-ayodejicoker@ futminna.edu.ng; Phone no: 08034091353
}

\begin{abstract}
The Growth Enhancement Support Scheme (GESS) is aimed at stimulating a thriving private sector fertilizer and seed industry and enhancing agricultural productivity while ensuring complete withdrawal of government from the procurement and distribution of agricultural inputs. This study therefore assessed the effect of the GESS agro-input s support on rice production in Nigeria, while identifying emerging issues for sustainable development within a green economy. Secondary data covering the 36 States of the Country and FCT were used. Multiple regression and content analysis were employed for data analysis. The research revealed that GESS agro-inputs (fertilizers and improved seeds) had no effect on rice production during the 2012 farming season while area put under cultivation was significant at $1 \%$ probability level, implying that one hectare increase in land area will enhance rice output by 1.01 metric tome. Key issues arising from the study were among others, included exploring the benefits of untapped land area for rice production without prejudice to productivity concerns; ensuring successful green economy that will facilitate sustainable development; effectively complementing activities under the GESS with sustainable initiatives and changing the mindset of the rice farmers, including the slow legislative approvals of existing laws. Arising from these, the study recommended the need for: sustained awareness on sustainable practices and effective extension system to support rice farmers; integrating sustainable organic and affordable more environmentally friendly synthetic technologies within GESS framework while taking full advantage of the IFAD's Adaptation for Small-holder Agriculture Programme (ASAP) under the proposed Community Based Agriculture and Rural Development Programme-II. Finally, the current Agricultural Transformation Agenda should also holistically and effectively relate and upscale sustainability concerns within its implementation framework in consonance with the Rio + 20 Agenda and fast track legislative approvals, with a view to ensuring unhindered implementation.
\end{abstract}

Keywords: Growth Enhancement Support, Agro-inputs, rice, green economy, sustainable development

\section{INTRODUCTION}

The issue of low agricultural productivity in Nigeria has been a recurring decimal since independence. According to the FMARD (2011), annual crop yield growth rate between 1961 and 2008 stood at $1.2 \%$ compared to $2.3 \%$ for Indonesia and $3 \%$ for Malaysia. The source further noted that the country currently has a low agro-input usage and ranks at the bottom of global agricultural input consumption index. Fertilizer utilization was put at $13 \mathrm{~kg} / \mathrm{ha}$ compared to $150 \mathrm{~kg} / \mathrm{ha}$ for Asia and $100 \mathrm{~kg} / \mathrm{ha}$ globally. Similarly, its use of improved seeds stood at $5 \%$ of farming households compared to $25 \%$ for East Africa and $60 \%$ for Asia

Rice is one of the major staples in Nigeria with low yield record. Its yield ranged from $1.95 \mathrm{mt} / \mathrm{ha}$ - $2.18 \mathrm{mt} /$ ha between 1999 and 2010 (FMARD, 2011) compared to the $2.6 \mathrm{mt} / \mathrm{ha}$ under national agricultural research conditions. As at 2013, the average rice yield for the country stood at 2.23 $\mathrm{mt} / \mathrm{ha}$ and ranged from $1.08 \mathrm{mt} / \mathrm{ha}$ at Yobe State to $4.22 \mathrm{mt} / \mathrm{ha}$ in the Federal Capital Territory 
(FMARD, 2014). Akintayo et al,, (2011) in their work in North Central Nigeria observed an average yield gap of $2.64 \mathrm{mt} / \mathrm{ha}$ for 4 varieties of rice.

Thus, the Growth Enhancement Support Scheme (GESS), being one of the key pillars of the Agricultural Transformation Agenda (ATA) in the country, is meant to reform the agro-input sector and stimulate productivity, complemented with protectionist trade policies for key commodities which the country has comparative advantage, especially rice, with the view for import substitution and export drive. The Growth Enhancement Support Scheme (GESS) is aimed among others at stimulating a thriving private sector fertilizer and seed industry; ensuring complete withdrawal of government from the procurement and distribution of agro- inputs; facilitating private sector commercialization of seeds and fertilizers to reach farmers directly and providing support to farmers directly through the GESS while expunging corruption from the agroinput value-chain. The GESS is expected to move farmers from subsistence to commercialized farming through fiscal savings, greater returns on investment, targeting highest poverty level and providing exit strategy. The programme targets 20 million farmers by 2015 in phased manner and is expected to result in a total programme benefit of US $\$ 40$ billion, a 16 fold benefit versus cost, aside the financial benefit of US\$500 per farmer (FMARD 2011). The initiative is also expected to leverage the use of mobile technology to achieve scale (electronic wallet). The implementation of the programme is on-going with over 10 million farmers reached (over $50 \%$ achievement). According to Cellulant, the GESS in dollar terms effected $\$ 294 \mathrm{~m}$ value of subsidies disbursement on behalf of the Federal and State Governments into the wallets of farmers. The organization noted that while farmers used $\$ 52$ million of the subsidy deposits, agro-dealers received $\$ 50$ million as matching funds from farmers, thereby accruing a saving of about \$192 million ( $\$ 29.7$ billion).

In-spite of this development however, an international organization noted that the scheme may not have been effective on ground while some farmers across the country have also expressed their inability to redeem inputs under the scheme. A cursory review of available data also revealed that only $8 \%$ of the total farm families in the country were covered during the 2012 wet season when the 1,128, 673 farmers redeemed with agro-inputs is placed against the $14,505,207$ farming households in the country; even though, 20,000,000 farmers were targeted under the scheme with 12 million reached (registered) as at the close of 2013 farming season. Discussions with facilitators of the initiative within the Federal Ministry of Agriculture and Rural Development and National Programme for Food Security confirmed that substantial numbers of farmers are yet to be serviced. This is not however implying that some iota of success has not been recorded under the scheme. Never the less, the ensuing development raises some concerns about the adequacy of agroinputs provided, effectiveness of input use under the scheme in the context of environmental concerns while ensuring sustainable agricultural development. Agenda 21 of the 1992 Earth Summit in Rio envisioned an increase in food production and availability leading to a significant decline in hunger, a substantial reduction in poverty, improved conditions in critical ecosystems, and better integration of antipoverty efforts and natural resource management. The situation further questions the existing regulatory framework for the use of the inputs redeemed by farmers, especially as arrangements are on for the introduction of the genetically modified and engineered seeds. While recognizing the importance of agriculture for poverty reduction and sustainable development, Rio +20 also noted the need for sustainable intensification of agricultural production and creating awareness for the necessary mosaic of solutions.

It is thus against this backdrop, that this study seeks to ascertain the effect of the GESS agro-input support on rice production within the country and its implication for the achievement of sustainable development and green economy. The objectives of the study were to ascertain the (i) effect of the growth enhancement agro-input support on rice output in Nigeria and (ii) identify and discuss emerging issues for sustainable development and the green economy in the country. The study is justified given that it will enable policy makers fine-tune the strategy for the scheme to achieve inclusive and sustainable development through a green economy in Nigeria. 


\section{MATERIALS AND METHODS}

Study Area: The study was conducted in Nigeria, located in West Africa and bordered by Cameroon to the south east, Benin to the southwest and Niger to the north. Nigeria has a population of about 140 million people, based on the 2006 National Population Census and 163 million based on National Population Commission's estimates (National Population Commission 2007 and National Bureau of Statistics, 2010). The country has a land area of $923,769 \mathrm{~km}^{2}$ with $853 \mathrm{~km}$ of its coastline along the northern part of the gulf of Guinea. The climate varies from semi-arid in the north to humid in the south with an average temperature of between $31^{\circ}$ and $28^{\circ} \mathrm{C}$ in the south. According to FRN (2012), more than $70 \%$ of the total farming population is composed of smallholder farmers, cultivating less than 5 ha and producing up to $90 \%$ of the total national output. The source further noted that agricultural growth has been relatively well performing at $7 \%$ as at 2012 , but was insufficient for longer term sustainable food security and poverty reduction (estimated to require a $10 \%$ growth rate). Poverty was also observed to be a rural phenomenon, with twothirds of the rural population considered poor, while the livelihood of smallholder farmers has been constrained by a host of challenges including low productivity; environmental challenges; limited access to productive assets and inputs; inadequate support services (extension and research), among others. The country comprises 36 States and the Federal Capital Territory, Abuja (Figure 1), 774 Local Government Areas and 109 senatorial districts. Major crops grown include cash crops such as cocoa, oil-palm, groundnut, cotton while the key arable crops cultivated include maize, rice, cowpea, sorghum, millet, yam and cassava. The country also has comparative advantage in livestock, fisheries and agro-forestry related activities.

Source: Urhobo Historical Society (www.waado.org/nigerdelta/maps/Nigeria_States. html)

Source of Data: Data used for the study were from secondary sources obtained from the Federal Ministry of Agriculture and Rural Development, National Programme for Food Security and the
National Bureau of statistics. Data covered the 2012 farming season and were on state basis.

\section{Analytical Technique:}

\section{Multiple Regression Analysis}

This tool was employed to determine the effect of the GESS agro-input support (fertilizer and seeds) on rice output. This was used to analyze objective I of this study

Hence, the model was specified as:

$\mathrm{Y}=\left(\begin{array}{lllll}\mathrm{X}_{1}, & \mathrm{X}_{2}, & \mathrm{X}_{3}, & \mathrm{X}_{4}, & \mathrm{X}_{5}\end{array}\right.$

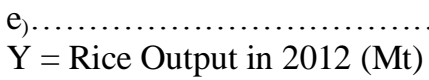

$\mathrm{X}_{1}=$ Area under rain-fed rice production in 2012 (Ha.)

$\mathrm{X}_{2}=$ Improved rice seed support under the GESS (Mt.)

$\mathrm{X}_{3}=$ Fertilizer support under the GESS (Mt.)

$\mathrm{X}_{4}=$ Farmers redeemed with agro-inputs under GESS in 2012 rain-fed (No.)

$\mathrm{X}_{5}=$ Farm families across States (No.)

$\mathrm{e}=$ Error term

The explicit forms of the model are specified as follows:

i. Linear Functional Form:

$\mathrm{Y}=$ bo $+\mathrm{b}_{1} \mathrm{X}_{1}+\mathrm{b}_{2} \mathrm{X}_{2}+\mathrm{b}_{3} \mathrm{X}_{3}+\mathrm{b}_{4} \mathrm{X}_{4}+\mathrm{b}_{5} \mathrm{X}_{5}$

+ e.................... (ii)

ii. Double Log (Cob Douglas) Functional Form:

$\mathrm{LnY}=\mathrm{bo}+\mathrm{b}_{1} \operatorname{Ln} \mathrm{X}_{1}+\mathrm{b}_{2} \mathrm{LnX}_{2}+\mathrm{b}_{3} \operatorname{Ln} \mathrm{X}_{3}+\mathrm{b}_{4} \mathrm{Ln}$ $\mathrm{X}_{4}+\mathrm{b}_{5} \operatorname{Ln} \mathrm{X}_{5}+{ }_{+} \mathrm{e} \ldots \ldots$ (iii)

iii. Semi-log Functional Form:

$\mathrm{Y}=\mathrm{bo}+\mathrm{b}_{1} \operatorname{Ln} \mathrm{X}_{1}+\mathrm{b}_{2} \operatorname{LnX}_{2}+\mathrm{b}_{3} \operatorname{LnX}_{3}+\mathrm{b}_{4} \operatorname{LnX}_{4}$ $+\mathrm{b}_{5} \mathrm{LnX}_{5}+\mathrm{e}$

iv. Exponential:

Lny $=$ bo+b $\mathrm{X}_{1}+\mathrm{b}_{2} \mathrm{X}_{2}+\mathrm{b}_{3} \mathrm{X}_{3}+\mathrm{b}_{4} \mathrm{X}_{4}+\mathrm{b}_{5} \mathrm{X}_{5}$ $+\mathrm{e}$.

Where bo- $b_{5}=$ Regression coefficients

$\mathrm{e}=$ Error term .

Content analysis will also be used to identify and discuss emerging issues from the study and their implications for sustainable development and the green economy in Nigeria. 


\section{RESULTS AND DISCUSSION}

Effect of Growth Enhancement Support AgroInput Support on Rice Output in Nigeria

From the results presented on Table 2, the double$\log$ functional form was chosen as the lead equation. The R square of .and, shows that $99 \%$ of the variation in rice output during the 2012 farming season in Nigeria was accounted for by the five included independent variables put together. The adjusted $\mathrm{R}$ square also supported the claim with a value of 0.99 or $99 \%$. This implies that the independent variables explained the behaviour of the dependent variables at $99 \%$ confidence. The calculated F-statistic probability value of 0.000 also implies that there is a significant impact between the dependent variables and the independent variables. From the result, the area put under rice cultivation during the 2012 rain-fed season appears to be a significant determinant of rice output. Thus, an increase of one hectare in the area cultivated for rice will increase output by one metric ton. Without prejudice to the focus on productivity, the result thus infers that higher rice output in the country can still come from increasing the area cultivated. Danbaba et al., (2013) noted that, of the 4.6 million hectares suitable for rice production in Nigeria, only 1.8 million hectares $(39 \%)$ is under rice cultivation However, the non significance of the key variables of interest
(GESS seed support $\mathrm{X}_{2}$ and fertilizer support $\mathrm{X}_{4}$ ) soaps that these agro-inputs do not currently influence the output of rice in Nigeria. This result therefore rejected the null hypothesis of the study that GESS agro-inputs has an effect on rice production in Nigeria. The ensuing development could be attributable to factors such as the initial take-off effect associated with development initiatives in the developing countries, limited outreach of the programme in terms of farmers reached and inputs redeemed, administrative and institutional challenges. As earlier noted only $8 \%$ of the targeted farming households were reached with agro-inputs during the 2012 rain-fed season going by the available data Osinowo (2012) attributed specific issues constraining the implementation of the initiative to bureaucratic resistance to change, low technical capabilities on the part of farmers and reliance on foreign institutions and models. NANT (2012) on the other hand hinted that budget limitations could limit achievements under ATA while Coker $\boldsymbol{e t}$ al., (2014) opined that there may have been mobilization related issues, administrative problems and ignorance on the part of the farmers. The emerging scenario is thus a source of worry, given that the e-wallet initiate was expected to obviate the challenges of the previous public sector procurement and distribution arrangement.

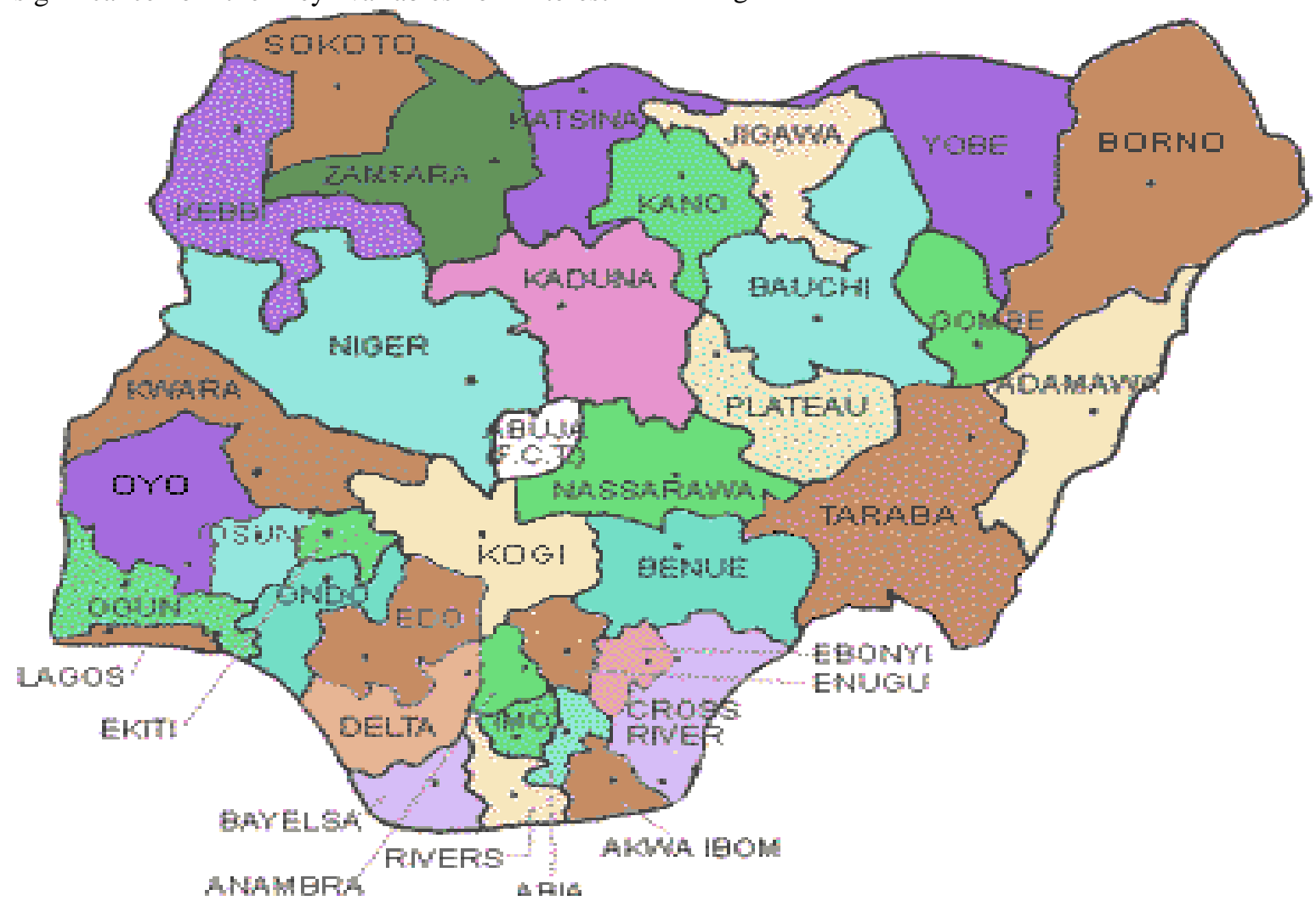

Figure 1: Map of Nigeria showing all States of the Federation 
Table 1: Estimated Current Yield vs. Potential Yield (Selected Crops - mt/ha)

\begin{tabular}{lll}
\hline Crop & Current Yield & Potential Yield \\
\hline Cassava & 12.3 & 28.4 \\
Yam & 12.3 & 18.0 \\
Rice & 1.9 & 7.0 \\
Maize & 1.4 & 4.0 \\
Sorghum & 1.1 & 3.2 \\
Millet & 1.1 & 2.4 \\
\hline Sources: Current yield from FMAWR/CBN; Potential yield from ReSAKSS (2009) & \\
Adapted from FRN (2010) & \\
The hypothesis put forwarded were as follows:
\end{tabular}

Ho: GESS has an effect on rice production in Nigeria

Ha: GESS has no effect on rice production in Nigeria

Effect of Growth Enhancement Fertilizer Support on Rice Output

Table 2: Results of Multiple Regression Analysis

\begin{tabular}{|c|c|c|c|c|}
\hline Variable & Linear & Exponential & Double-log & Semi-Log \\
\hline Constant & $\begin{array}{c}-5318.674 \\
(-0.18)\end{array}$ & $\begin{array}{l}8.151684 \\
(4.50)^{* * * *}\end{array}$ & $\begin{array}{c}-0.5725554 \\
(1.12)\end{array}$ & $\begin{array}{c}-678171.2 \\
(-2.32)\end{array}$ \\
\hline Area under Rice $(\mathrm{Ha})$ & $\begin{array}{c}2.178182 * * * \\
(21.14)\end{array}$ & $\begin{array}{c}0.0000148 * * * \\
(2.38)\end{array}$ & $\begin{array}{c}1.011042 * * * \\
(25.77)\end{array}$ & $\begin{array}{c}74205.02 * * * * \\
(3.30)\end{array}$ \\
\hline Quantities of rice redeemed $(\mathrm{Kg})$ & $\begin{array}{c}1134.797 \\
(1.04)\end{array}$ & $\begin{array}{c}-0.0102939 \\
(0.16)\end{array}$ & $\begin{array}{c}0.1419548 \\
(1.78)\end{array}$ & $\begin{array}{c}38984.32 \\
(0.85)\end{array}$ \\
\hline Farmers redeemed with fertilizers (No.) & $\begin{array}{c}-578.3813 \\
(-0.84)\end{array}$ & $\begin{array}{c}-0.0051284 \\
(-0.12)\end{array}$ & $\begin{array}{c}-0.0180978 \\
(-0.27)\end{array}$ & $\begin{array}{c}6768.693 \\
(0.18)\end{array}$ \\
\hline Quantity of fertilizer redeemed (Mt) & $\begin{array}{l}-1257.1 \\
(-1.67)\end{array}$ & $\begin{array}{c}0.0547986 \\
(1.18)\end{array}$ & $\begin{array}{c}-0.1178101 \\
(-1.67)\end{array}$ & $\begin{array}{c}-44453.86 \\
(-1.10)\end{array}$ \\
\hline Farm families (No) & $\begin{array}{c}1292.701 \\
(1.35)\end{array}$ & $\begin{array}{c}0.0463602 \\
(0.80)\end{array}$ & $\begin{array}{c}0.0345256 \\
\quad(0.36)\end{array}$ & $\begin{array}{c}27462.82 \\
(0.50)\end{array}$ \\
\hline R Square & 0.9902 & .6727 & 0.9911 & 0.6816 \\
\hline Adjusted R Square & 0.9840 & 0.4682 & 0.9856 & 0.4826 \\
\hline
\end{tabular}

*** Implies significance at $1 \%$

NB: The analysis did not capture rice production figures for some states in the country.

\section{Emerging Issues for Sustainable Development and Green Economy in Nigeria}

Arising from the results of this study, it thus implies that if Nigeria is to achieve sustainable development within the setting of a green economy, there will be need to fashion out sustainable approaches to enhancing production through land expansion and productivity increases with the view to meeting the food requirement of the nation. FMARD (2011) noted that Nigeria's food import bills, a proxy for the country's self sufficiency has been exceptionally high and are growing at an unsustainable rate of $11 \%$ per annum. The implication of this is that the country needed to focus on efficiency in the use of land for rice production in the country and productivity gains in addition to securing a favourable and easily accessible land use right for the rice farming households through amendments of the Land Use Decree, with the view to ensuring sustainable land use. Focus also needs to be directed at the use of synthetic fertilizers with the view to enhancing productivity and complementing short-falls under the GESS while not clamoring for sustained deployment of fertilizer as sustained public good for obvious policy issues of trying to overburden the state, dependency syndrome and dampening of initiatives. It has also become imperative to enhance the use of improved seeds and promptly finalize the regulatory framework for the proposed biological modified and engineered agro-input technology. This has become imperative given the growing population of the country estimated at 190 million by 2015 (UN Habitat, 2004) and the need to avoid the Malthusian trap which opined that the power of population is greater than the power in the earth to produce subsistence for man. In its "Towards a Green Economy Report", the UN Environment Programme (UNEP) argued that "greening" agriculture will require investment in soil-fertility management, sustainable water use, crop diversification, biological plant management, mechanization levels, storage facilities (especially for small farms), and supply chains - both upstream and downstream-for businesses and trade.

A major challenge however will be how the country, through a green economy, hopes to successfully achieve sustainable development and is expected to move the country towards redressing the burning issues of food insecurity 
and poverty alleviation. Arguments on this may likely support a more holistic dimension within the ATA framework which will invest heavily on awareness creation and ethical turn-around by majority of the farming households. The linkage of and the extent of involvement of the Federal Ministry of Environment in the ATA implementation arrangement outside meeting the environmental impact assessment concerns also remains an issue.

\section{CONCLUSION AND RECOMMENDATIONS}

The outcome of the study established that the GESS agro-inputs had no effect on rice productivity in Nigeria for the 2012 farming season, but that, land area was a significant factor. The research further noted the need for the country to exploit its land potentials, focus on efficient and environmentally sustainable practices with the view to achieving sustainable development within a green a green economy. Thus, the study recommends as follows: (i) Efforts needed to be made by the Federal Ministry of Agriculture and Rural Development under the GESS to reach more farmers with subsidized agro-inputs with the view to enhancing the impact on the initiative on rice production in Nigeria; (ii) There is the need for the FMARD to remove all identified bottlenecks hindering effective implementation of the scheme bordering on administration, weak mobilization, funding, and technological related issues; (iii) There is the need for the FMARD to go beyond rhetoric and hype and effectively actionalize the sustainable development angle of the agenda. Putting in place a workable framework, especially with respect to bio-technology and fast-tracking approval process at the legislative end will do a lot of good for the country; (iv) There is the need for sustained awareness creation for sustainable practices and extension support for dissemination of best practices to the farming households; (v) It has also become imperative for the on-going donor supported food security related programmes and projects within the country to effectively align with the ATA, given their comparative advantage in the areas of best practices such as sustainable agricultural initiatives in areas like on soil fertility management, integrated production practices, sustainable water use and environmental technologies; (vi) There is the need for country to fully embrace the IFAD Adaptation for Small Holder Agriculture Initiative (ASAP) which will come on board with the coming of the proposed IFAD Assisted Community Based Agricultural and Rural Development Programme-II in Nigeria. (vii) It may also be imperative to reform and sustain the FAO South-South Cooperation initiative in Nigeria which deployed lots of small scale and adaptable technologies under the ongoing National Programme for Food Security; (viii) There is the need for the FMARD to effectively link ATA's operations with the Songhai Schools, with the view to building capacity and enhancing the transmission and adaptation of sustainable technology within the framework of ATA; (ix) There should be effective and close working relationship between the FMARD and Federal Ministry of Environment to take cognizance and redress environmental concerns relating to ATA implementation; and (x) finally, the agro-input dealers should now take up extension activities as part of their mandates with a view to disseminating sustainable practices related to their agro-based products.

\section{REFERENCES}

Akintayo, O.I., Rahji, M.A.Y., Awoyemi, T.T. and Adeoti, A.I. (2011). Determinants of Yield Gap in Lowland Rice Production in North central Nigeria. Agrosearch II $\begin{array}{llll}\text { No } & 1 & \& 2 & 1-\end{array}$ 10.http:dx.doi.org/10.4314/agrash.v/i/.i.

Danbaba, N., Ukungwu, M. N. Josiah, U., Ernest, A. A. and Sosson, L.(2003). Enhancing access to technology for improved parboiled rice processing and marketability in Nigeria. International Journal of Applied Research Technology 2(1): 28-37

Federal Ministry of Agricultural and Rural Development (FMARD), (2011). Presidential Brief Agricultural Transformation Agenda. We will grow Nigeria's Agriculture Sector. Presentation by the Honorable Minister of Agriculture to the Economic Management Team.

Federal Ministry of Agricultural and Rural Development (FMARD), (2011). Agricultural Production Survey Data (Several Years).

Federal Ministry of Agricultural and Rural Development (FMARD), (2014). 2013 Agricultural Production Survey Data. FCT, Abuja.

Federal Republic of Nigeria (FRN), (2012). Value Chain development Programme

$$
\text { Coker, A. A. }
$$

Osinowo, O. A. (2012). Agricultural Transportation in a Deregulated Economy: The role of Livestock Subsector. Proceedings of the 46th 
Annual Conference of Agricultural Society of Nigeria, Head at Bayero University Kano. p. 4.

National Association of Nigerian Traders (NANTS), (2012). 2012 Nigeria Agriculture Budget Appraisal. Policy Advocacy Series. Pp 1-12.

National Bureau of Statistics (NBS), (2012). Nigeria Poverty Profile 2010. Federal Capital Territory, Abuja, Nigeria.
National Population Commission (NPC), (2007). National Population Figures.

UN Environnent Programme (UNEP), (2012). Towards a Green Economy Report.

UN Habitat, (2004). The State of the World's Cities. Urhobo Historical Society (www.waado.org/nigerdelta/maps/Nigeria_States. html) 